\title{
Integrated Oxidative Folding of Cysteine/Selenocysteine Containing Peptides: Improving Chemical Synthesis of Conotoxins $^{* *}$
}

\author{
Aleksandra Walewska, M.Sc., \\ Department of Biology, University of Utah, Salt Lake City, Utah 84108, USA. Faculty of \\ Chemistry, University of Gdansk, Gdansk 80-952, Poland \\ Dr. Min-Min Zhang, \\ Department of Biology, University of Utah, Salt Lake City, Utah 84108, USA \\ Prof. Jack J. Skalicky, \\ Department of Biochemistry University of Utah Salt Lake City, Utah 84108, USA \\ Prof. Doju Yoshikami, \\ Department of Biology, University of Utah, Salt Lake City, Utah 84108, USA \\ Prof. Baldomero M. Olivera, and \\ Department of Biology, University of Utah, Salt Lake City, Utah 84108, USA \\ Grzegorz Bulaj \\ Department of Medicinal Chemistry, University of Utah, 421 Wakara Way, Suite 360, Salt Lake \\ City, Utah 84108, USA, Fax: (+) 1-801-581-7087, \\ www.pharmacy.utah.edu/medChem/faculty/Bulaj/
}

Grzegorz Bulaj: bulaj@pharm.utah.edu

\begin{abstract}
Chemical synthesis of disulfide-rich peptides requires improvements in oxidative folding and disulfide mapping. To address these challenges, we combined the use of diselenide and selectively $\left({ }^{15} \mathrm{~N} /{ }^{13} \mathrm{C}\right)$-labeled disulfide bridges. Conotoxin analogs, each with a pair of selenocysteines and labeled cysteines, exhibited significantly improved folding while the labeled cysteines allowed correctly folded species to be rapidly identified by NMR.
\end{abstract}

\section{Keywords}

diselenide; disulfide; oxidative folding; NMR; conotoxin

\begin{abstract}
Bioactive disulfide-rich peptides, such as neurotoxins from spiders, scorpions, cone snails, and plant cyclotides, antibacterial peptides and protease inhibitors form a megadiverse group of natural products estimated to consist of millions of distinct sequences. Many of these peptides are promising drug leads as analgesics, antihypertensive, antiarrhythmic, antitumor, antiviral or antibiotic therapeutics. ${ }^{[1-3]}$ However, an efficient oxidative folding and
\end{abstract}

\footnotetext{
** This work was supported in part by the NIH grants: R21 NS055845 (GB) and Program Project GM 48677 (BMO, GB, DY). We thank Drs. Robert Schackmann and Scott Endicott from the DNA/Peptide Synthesis Core for their help with chemical synthesis. GB is a scientific cofounder of NeuroAdjuvants, Inc. and BMO is a scientific cofounder of Cognetix, Inc..

Correspondence to: Grzegorz Bulaj, bulaj@pharm. utah. edu.

Supporting information for this article is available on the WWW under http://www.angewandte.org or from the author.
} 
determination of resulting disulfide connectivities are the most common bottlenecks in their chemical syntheses that slow the progress of drug discovery and development. ${ }^{[4]}$ To address these two challenges simultaneously, we developed an integrated approach that combines the use of diselenide and selectively $\left({ }^{15} \mathrm{~N} /{ }^{13} \mathrm{C}\right)$-labeled disulfide bridges. We synthesized conotoxin analogs, in which the selenocysteines significantly improved folding yields while the labeled cysteines allowed the correctly folded species to be rapidly identified by NMR spectroscopy.

Numerous strategies have been developed to improve the oxidative folding of disulfide-rich peptides. ${ }^{[5,6]}$ A replacement of disulfide bridges by more redox-stable diselenide crosslinks has beenemployed for peptides containing either one or two disulfide bridges. ${ }^{[7-12]}$ Substitution of a pair of cysteines with selenocysteines should guide the formation of disulfide bridges between remaining cysteines, ${ }^{[8]}$ since the more stable diselenide forms first (the redox potential of a diselenide bridge $\left(\mathrm{E}_{\mathrm{O}}=-381 \mathrm{mV}\right)$ is significantly lower than that of a disulfide bridge $\left.\left(\mathrm{E}_{\mathrm{O}}=-180 \mathrm{mV}\right)^{[13]}\right)$ providing a topological constraint for the formation of the remaining disulfides and reducing the number of possible disulfide connectivities. ${ }^{[14]}$ Once a disulfide-rich peptide is synthesized and oxidized, the disulfide bridges must be determined. To overcome multiple challenges of traditional disulfide mapping, we recently developed an NMR-based strategy to rapidly determine disulfides using differential isotope labeling of pairs of Cys, followed by detecting NOESY crosspeaks between cross-disulfide $\mathrm{H}^{\alpha} / \mathrm{H}^{\beta 2} / \mathrm{H}^{\beta 3}$ protons. ${ }^{[15]}$ Our on-going search for improved oxidation strategies led us to the strategy of combining selenocysteines and ${ }^{15} \mathrm{~N} /{ }^{13} \mathrm{C}$-labeled cysteines, which we successfully applied to $\mu$-conotoxins.

The concept of "integrated oxidative folding" is illustrated in Figure 1a. For three-disulfidebridged peptides, the analogs containing diselenide and the isotope-labeled disulfide bonds should: (1) fold more efficiently, since the pre-existing diselenide bridge reduces the number of possible disulfide crosslinks and directs formation of the remaining disulfides, and (2) provide unambiguous evidence of the correct pairing of all three crosslinks; the crossdisulfide NOESY crosspeaks from the selectively-labeled pair of the cysteine residues and the thermodynamically-preferred diselenide bridge would suffice to make such a claim. To obtain proof-of-concept, we selected the three disulfide-bridged peptide, $\mu$-conotoxin SIIIA, for which folding, structure and function were well studied. ${ }^{[16-19]}$ Figure $1 \mathrm{~b}$ shows the structure of SIIIA and three analogs in which one pair of the cysteine residues forming a native disulfide bridge was replaced by a pair of selenocysteine residues. The analogs were synthesized using the Fmoc-based chemistry. The cysteine thiols were protected with the trityl groups, whereas selenocysteine residues were protected with 4-methoxybenzyl (Mob) groups. Both protecting groups were removed during the cleavage of the peptides from the resin. The Mob group came off easily with 2-2'-dithiobis-(5-nitropyridine) (DTNP). A mechanism underlying the removal of the Mob group and the formation of the diselenide bridge was recently studied. ${ }^{[20,21]}$ A critical step in an efficient recovery of the reduced conotoxins containing a diselenide bridge appeared to be the reduction of the crude (postcleavage) peptide with dithiothreitol. Mass spectrometry analysis confirmed the existence of the preformed diselenide bridge in the otherwise reduced SIIIA analogs (an alkylation of free Cys thiols with 4-vinylpyridine yielded SIIIA[C3U,C13U] = 2726.9, SIIIA[C4U,C19U] $=2726.7$, SIIIA[C8U,C20U] $=2727.0$ ).

The diselenide-containing peptides were subjected to oxidative folding in the mixture of the oxidized (1 mM GSSG) and reduced (10 mM GSH) glutathione (Figure 2). The identity of each folded analog $\left(\left[\mathrm{MH}^{+}\right]_{\text {calc }}=2302.7\right)$ was confirmed by MALDI-TOF: SIIIA[C3U,C13U] $\left[\mathrm{MH}^{+}\right]_{\exp }=2302.5$, SIIIA $[\mathrm{C} 4 \mathrm{U}, \mathrm{C} 19 \mathrm{U}]\left[\mathrm{MH}^{+}\right]_{\exp }=2302.6$, SIIIA[C8U,C20U] $\left[\mathrm{MH}^{+}\right]_{\exp }=2302.4$. The highest steady-state accumulation of the native form was found for SIIIA[C3U,C13U] and the lowest for SIIIA. The number of the folding 
intermediates was much lower for all three diselenide-containing analogs compared to SIIIA, and only few minor folding species were detected to contain mixed disulfides with glutathione, as determined by mass spectrometry. Noteworthy, further improvements of the folding yields might be achieved by optimizing concentrations of GSSG and GSH. All SIIIA analogs blocked $\mathrm{Na}_{\mathrm{v}} 1.2$ subtype of voltage-gated sodium channels (Supplemental Table S1 and Figure S1) with the $\mathrm{K}_{\mathrm{d}}$ values were: $47 \pm 16 \mathrm{nM}$ for SIIIA, $46 \pm 38 \mathrm{nM}$ for SIIIA[C3U,C13U], $67 \pm 18 \mathrm{nM}$ SIIIA[C4U,C19U] and $37 \pm 6$ SIIIA[C8U,C20U] (mean \pm $\mathrm{SD}, \mathrm{N} \geq 3$ ).

The position-specific introduction of the ${ }^{15} \mathrm{~N} /{ }^{13} \mathrm{C}$ labeled Cys residues in $\mu$-selenoconotoxin SIIIA analogs, (Figure 1b), allowed us to rapidly determine the disulfide connectivities. The ${ }^{15} \mathrm{~N} /{ }^{13} \mathrm{C}$-labeled cysteines in the two $\mu$-selenoconotoxin analogs, SIIIA[C $3 \mathrm{U}, \mathrm{C} 13 \mathrm{U},{ }^{15} \mathrm{~N} /{ }^{13} \mathrm{C}$ enriched $\mathrm{C} 4$ and C19] and SIIIA $\left[{ }^{15} \mathrm{~N} /{ }^{13} \mathrm{C}\right.$ enriched $\mathrm{C} 3$ and $\mathrm{C} 13, \mathrm{C} 4 \mathrm{U}, \mathrm{C} 19 \mathrm{U}]$, were identified in $2 \mathrm{D}\left[{ }^{13} \mathrm{C},{ }^{1} \mathrm{H}\right]$ HSQC experiments. The methine and methylene resonances were assigned in both analogs using the reported chemical shifts for $\mu$-SIIIA (Figure 3). ${ }^{[19]}$ Following resonance assignment, 2D ${ }^{13} \mathrm{C}$-F2-edited NOESY was recorded to identify cross-disulfide NOEs consistent with a disulfide bond. These are shown with red rectangles in panels $b$ and $d$ in Figure 3. Thus, we were able to deduce the proper connectivity of the crosslinks in the $\mu$-selenoconotoxin analogs by: (1) preforming the diselenide bridge, and (2) detecting cross-disulfide NOEs for the disulfide bond with ${ }^{13} \mathrm{C} /{ }^{15} \mathrm{~N}$ enrichement.

To examine applications of $\mu$-selenoconotoxins for peptide engineering, we designed two nonnatural selenoconotoxin SIIIA analogs (Figure 4): in the first analog, AHX-Sec-SIIIA, two adjacent Ser residues were replaced by 6-aminohexanoic acid, whereas the second analog, DOTA-Sec-SIIIA, contained Lys-DOTA at the N-terminus. The oxidative folding of both analogs resulted in an accumulation of a single major species (Figure 4c). Both analogs retained the ability to block $\mathrm{Na}_{\mathrm{V}} 1.2$ sodium currents, and the DOTA-Sec-SIIIA was fluorescent when it chelated terbium $\left(\mathrm{Tb}^{+3}\right)$ (Supplemental Figure S2). To investigate whether other $\mu$-selenoconotoxins also exhibit improved folding properties, we introduced a pair of selenocysteines into poorly-folding $\mu$-conotoxin SmIIIA. ${ }^{[22]}$ The folding yield the SmIIIA[C3U,C15U] (41\%) was significantly improved as compared to the wild-type peptide $(12 \%)$, whereas the replacement of disulfide by diselenide bridges did not markedly compromise bioactivity (Supplemental Fig S3).

In this work, we describe a novel approach to oxidative folding of disulfide-rich peptides that combines the use of diselenide and selectively $\left({ }^{15} \mathrm{~N} /{ }^{13} \mathrm{C}\right)$-labeled disulfide bridges: introduction of selenocysteines significantly improves folding yields while the labeled cysteines allow the correctly folded species to be rapidly identified by NMR. Integrated oxidative folding opens new opportunities in chemical syntheses of peptides containing even four disulfide bridges (Supplemental Figure S4). Since this technology is compatible with higher throughput chemical syntheses, it will also accelerate drug discovery and development. For larger polypeptides, this strategy may be exploited in conjuction with recombinant methods or native chemical ligation. ${ }^{[23,24]}$ Furthermore, integrated oxidative folding is useful in studying folding mechanisms, since it offers a means of dissecting a role of individual (native and nonnative) disulfide bridges in the folding pathways. Taken together, the integrated oxidative folding approach is likely to impact basic and applied research of disulfide-rich peptides.

\section{Experimental Section}

Peptides were synthesized using standard Fmoc [N-(9-fluorenyl)methoxycarbonyl] chemistry, as described ${ }^{[16,22]}$. Fmoc-protected selenocysteine with the Se-p-methoxybenzyl 
protection was purchased from ChemImpex International, Inc., (Wood Dale, IL). Fmocprotected ${ }^{15} \mathrm{~N} /{ }^{13} \mathrm{C}$ cysteine residue (U-13C3, 97-99\%; $\left.15 \mathrm{~N}, 97-99 \%\right)$ was obtained from Cambridge Isotope Laboratories, Inc. (Andover, MA). Cysteine residues were protected with S-trityl groups. Peptides were cleaved from the resin for $4 \mathrm{hr}$ with the enriched reagent K (TFA/thioanisole/phenol/water; (90:2.5:7.5: 5, v/v/v/v) + 1.3 eqv. DTNP [2, 2'dithiobis(5-nitropyridine)] ${ }^{[20]}$. The selenoconotoxins were washed with methyl tert-butyl ether and treated for $2 \mathrm{hr}$ with $50 \mathrm{mM}$ DTT, $0.1 \mathrm{M}$ Tris, $1 \mathrm{mM}$ EDTA, pH 7.5 at RT, then quenched with $8 \%$ formic acid. The peptides were purified using a C18 HPLC and gradient from 5 to $30 \%$ of $0.1 \%$ (v/v) TFA in $90 \%$ acetonitrile in $25 \mathrm{~min}$. Oxidative folding was performed in $0.1 \mathrm{M}$ Tris-HCl, $1 \mathrm{mM}$ EDTA (pH 7.5), $1 \mathrm{mM} \mathrm{GSSG}, 10 \mathrm{mM}$ GSH at RT. SIIIA[C3U,C13U]DOTA ( $220 \mathrm{nmol})$ was dissolved in $220 \mu \mathrm{l}$ water, then $40 \mu \mathrm{L}$ of ammonium acetate $(\mathrm{pH} 6.1)$ and $22 \mu \mathrm{L}(0.01 \mathrm{M})$ terbium (III) chloride hexahydrate were added. The mixture was shaken at $50{ }^{\circ} \mathrm{C}$ overnight, $\mathrm{pH}$ was adjusted to 9 with $10 \mathrm{mM}$ $\mathrm{NaOH}$. The solution was shaken for $30 \mathrm{~min}$ at $0^{\circ} \mathrm{C}$, centrifuged at $7000 \mathrm{RPM}$ for $5 \mathrm{~min}$, filtered through a $0.22 \mu \mathrm{m}$ filter, then washed with water and vacuum-dried.

Two-dimensional $\left[{ }^{13} \mathrm{C},{ }^{1} \mathrm{H}\right] \mathrm{HSQC}$ and $2 \mathrm{D}\left[{ }^{1} \mathrm{H},{ }^{1} \mathrm{H}\right]$ NOESY were recorded $[25]$ at $15^{\circ} \mathrm{C}$ on a Varian Inova 600 NMR spectrometer with a cryogenic ${ }^{1} \mathrm{H} /{ }^{13} \mathrm{C} /{ }^{15} \mathrm{~N}$ probe. Data were processed with FELIX2004 and analyzed using SPARKY (T. D. Goddard and D. G. Kneller, UCSF). Chemical shifts are published ${ }^{[19]}$.

Electrophysiological assays were carried out as described in Zhang et al, ${ }^{[26]}$.

\section{Supplementary Material}

Refer to Web version on PubMed Central for supplementary material.

\section{References}

1. Beeton, CE.; Gutman, GA.; Chandy, KG. Handbook of Biologically Active Peptides. Kastin, AJ., editor. Academic Press; 2005. p. 403

2. Han TS, Teichert RW, Olivera BM, Bulaj G. Curr Pharm Des. 2008; 14:2462. [PubMed: 18781995]

3. Craik DJ, Clark RJ, Daly NL. Expert Opin Investig Drugs. 2007; 16:595.

4. Bulaj G. Curr Opin Chem Biol. 2008; cr12:441. [PubMed: 18678277]

5. Moroder L, Musiol HJ, Gotz M, Renner C. Biopolymers. 2005; 80:85. [PubMed: 15612050]

6. Bulaj G, Olivera BM. Antioxid Redox Signal. 2008; 10:141. [PubMed: 17961068]

7. Pegoraro S, Fiori S, Rudolph-Bohner S, Watanabe TX, Moroder L. J Mol Biol. 1998; 284:779. [PubMed: 9826515]

8. Pegoraro S, Fiori S, Cramer J, Rudolph-Bohner S, Moroder L. Protein Sci. 1999; 8:1605. [PubMed: 10452604]

9. Fiori S, Pegoraro S, Rudolph-Bohner S, Cramer J, Moroder L. Biopolymers. 2000; 53:550. [PubMed: 10766951]

10. Moroder L. J Pept Sci. 2005; 11:187. [PubMed: 15782428]

11. Armishaw CJ, Daly NL, Nevin ST, Adams DJ, Craik DJ, Alewood PF. J Biol Chem. 2006; 281:14136. [PubMed: 16500898]

12. Muttenthaler M, Alewood PF. J Pept Sci. 2008; 14:1223. [PubMed: 18951416]

13. Besse D, Siedler F, Diercks T, Kessler H, Moroder L. Angewandte Chemie-International Edition. 1997; 36:883.

14. Price-Carter M, Bulaj G, Goldenberg DP. Biochemistry. 2002; 41:3507. [PubMed: 11876659]

15. Walewska A, Skalicky JJ, Davis DR, Zhang MM, Lopez-Vera E, Watkins M, Han TS, Yoshikami D, Olivera BM, Bulaj G. J Am Chem Soc. 2008; 130:14280. [PubMed: 18831583]

16. Bulaj G, West PJ, Garrett JE, Watkins M, Zhang MM, Norton RS, Smith BJ, Yoshikami D, Olivera BM. Biochemistry. 2005; 44:7259. [PubMed: 15882064] 
17. Green BR, Catlin P, Zhang MM, Fiedler B, Bayudan W, Morrison A, Norton RS, Smith BJ, Yoshikami D, Olivera BM, Bulaj G. Chem Biol. 2007; 14:399. [PubMed: 17462575]

18. Schroeder CI, Ekberg J, Nielsen KJ, Adams D, Loughnan ML, Thomas L, Adams DJ, Alewood PF, Lewis RJ. J Biol Chem. 2008; 283:21621. [PubMed: 18522941]

19. Yao S, Zhang MM, Yoshikami D, Azam L, Olivera BM, Bulaj G, Norton RS. Biochemistry. 2008; 47:10940. [PubMed: 18798648]

20. Harris KM, Flemer S Jr, Hondal RJ. J Pept Sci. 2007; 13:81. [PubMed: 17031870]

21. Beld J, Woycechowsky KJ, Hilvert D. Biochemistry. 2008; 47:6985. [PubMed: 18553979]

22. Fuller E, Green BR, Catlin P, Buczek O, Nielsen JS, Olivera BM, Bulaj G. Febs J. 2005; 272:1727. [PubMed: 15794759]

23. Besse D, Budisa N, Karnbrock W, Minks C, Musiol HJ, Pegoraro S, Siedler F, Weyher E, Moroder L. Biol Chem. 1997; 378:211. [PubMed: 9165073]

24. Hondal RJ, Nilsson BL, Raines RT. J Am Chem Soc. 2001; 123:5140. [PubMed: 11457362]

25. Cavanagh, J.; Fairbrother, WJ.; Palmer, AGr; Skelton, NJ. Protein NMR Spectroscopy, Principles and Practice. Academic Press; San Diego: 1996.

26. Zhang MM, Green BR, Catlin P, Fiedler B, Azam L, Chadwick A, Terlau H, McArthur JR, French RJ, Gulyas J, Rivier JE, Smith BJ, Norton RS, Olivera BM, Yoshikami D, Bulaj G. J Biol Chem. 2007; 282:30699. [PubMed: 17724025] 
a)

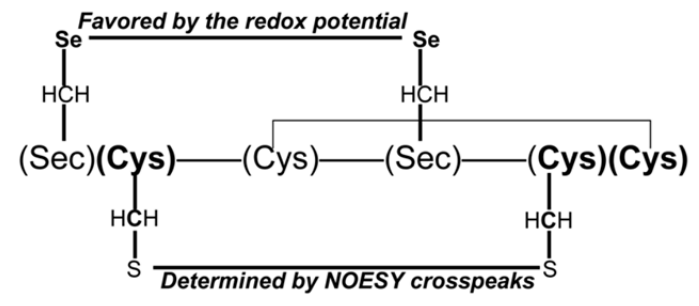

b) ZNCCNGGCSSKWCRDHARCC

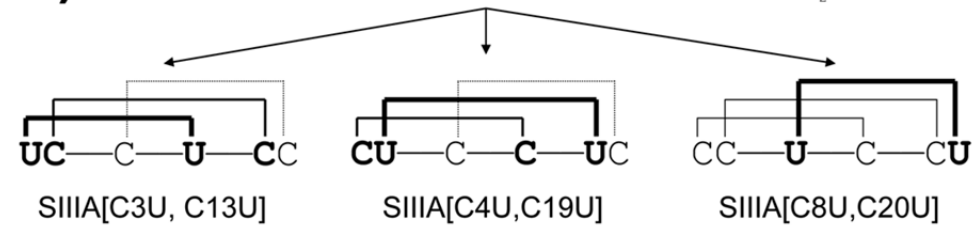

Figure 1.

Concept of the integrated oxidative folding. (a) $\mu$-Conotoxin scaffold containing one diselenide bridge, one isotope-labeled disulfide bridge and one normal disulfide bridge. The formation of the diselenide bridge is thermodynamically preferred and improves the oxidative folding, while the formation of the labeled disulfide bridge is readily confirmed by detecting crossdisulfide NOEs. (b) Structures of $\mu$-SIIIA and $\mu$-selenoconotoxin analogs of SIIIA studied in this work. 


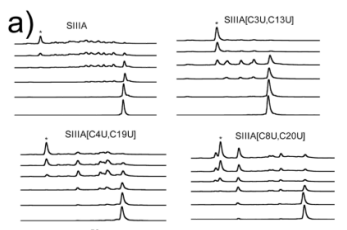

b)

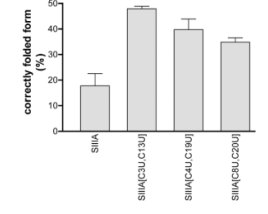

Figure 2.

Oxidative folding of $\mu$-selenoconotoxin SIIIA analogs. (a) HPLC elution profiles of $\mu$-SIIIA and $\mu$-selenoconotoxin analogs of $\mu$-SIIIA folded with a mixture of $1 \mathrm{mM}$ oxidized and 10 $\mathrm{mM}$ reduced glutathione. The oxidation mixtures were quenched by acidification after 1,10 , 30,60 , and 120 min and analyzed by reversed-phase $\mathrm{C}_{18}$ analytical HPLC. Asterisk indicates the native form of the peptide; labeled peaks were collected and analyzed by mass spectroscopy. (b) Correctly folded yields at the steady-state of $\mu$-SIIIA and its $\mu$ selenoconotoxin analogs. Error bars represent standard errors $(\mathrm{N}=3)$. 


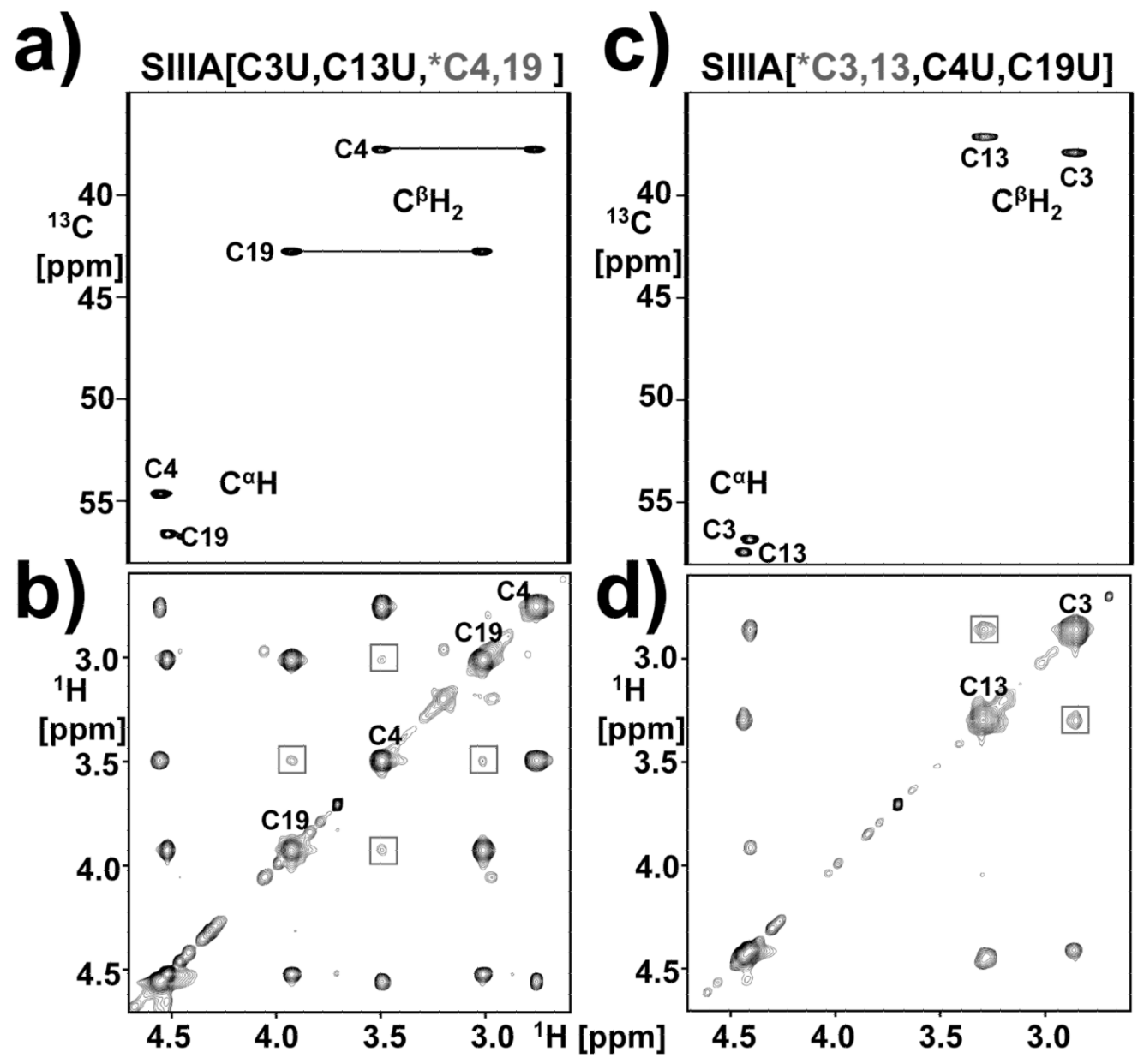

Figure 3.

NMR-based determination of disulfides in two $\mu$-selenoconotoxin SIIIA analogs. NMR spectra at $15{ }^{\circ} \mathrm{C}$ for $1 \mathrm{mM}$ SIIIA[C $3 \mathrm{U}, \mathrm{C} 13 \mathrm{U},{ }^{15} \mathrm{~N} /{ }^{13} \mathrm{C}$ enriched $\mathrm{C} 4$ and $\left.\mathrm{C} 19\right]$ prepared in 40 $\mathrm{mM} \mathrm{NaPi}\left(\mathrm{pH} 6.2\right.$ ), $50 \mathrm{mM} \mathrm{NaCl}, 90 \% \mathrm{H}_{2} \mathrm{O}$ and $10 \% \mathrm{D}_{2} \mathrm{O}$ is shown in panels a and $\mathrm{b}$, and SIIIA $\left[{ }^{15} \mathrm{~N} /{ }^{13} \mathrm{C}\right.$ enriched $\mathrm{C} 3$ and $\left.\mathrm{C} 13, \mathrm{C} 4 \mathrm{U}, \mathrm{C} 19 \mathrm{U}\right]$ in identical solution conditions is shown in panels $\mathrm{c}$ and $\mathrm{d}$. Panels a and $\mathrm{c}$ show the $2 \mathrm{D}\left[{ }^{13} \mathrm{C},{ }^{1} \mathrm{H}\right]$ constant time HSQC and panels $\mathrm{b}$ and $\mathrm{d}$ the $2 \mathrm{D}{ }^{13} \mathrm{C}$-F2-edited $\left[{ }^{1} \mathrm{H},{ }^{1} \mathrm{H}\right]$ NOESY. The proton dimensions (abscissa) are aligned for panel pairs a/b and c/d. Non-degenerate $\mathrm{C} 4$ and $\mathrm{C} 19 \mathrm{C}^{\beta} \mathrm{H}_{2}$ 's are connected with a line (shown in panel a), the degenerate $\mathrm{C} 3$ and $\mathrm{C} 13 \mathrm{C}^{\beta} \mathrm{H}_{2}$ 's are shown in panel c. NOE crosspeaks confirming the $\mathrm{C} 4-\mathrm{C} 19$ and $\mathrm{C} 3-\mathrm{C} 19$ disulfides are boxed. Intraresidue NOEs can be easily traced in the figure. A few natural abundance signals are present in the NOESYs but posed no problems with interpretation. 

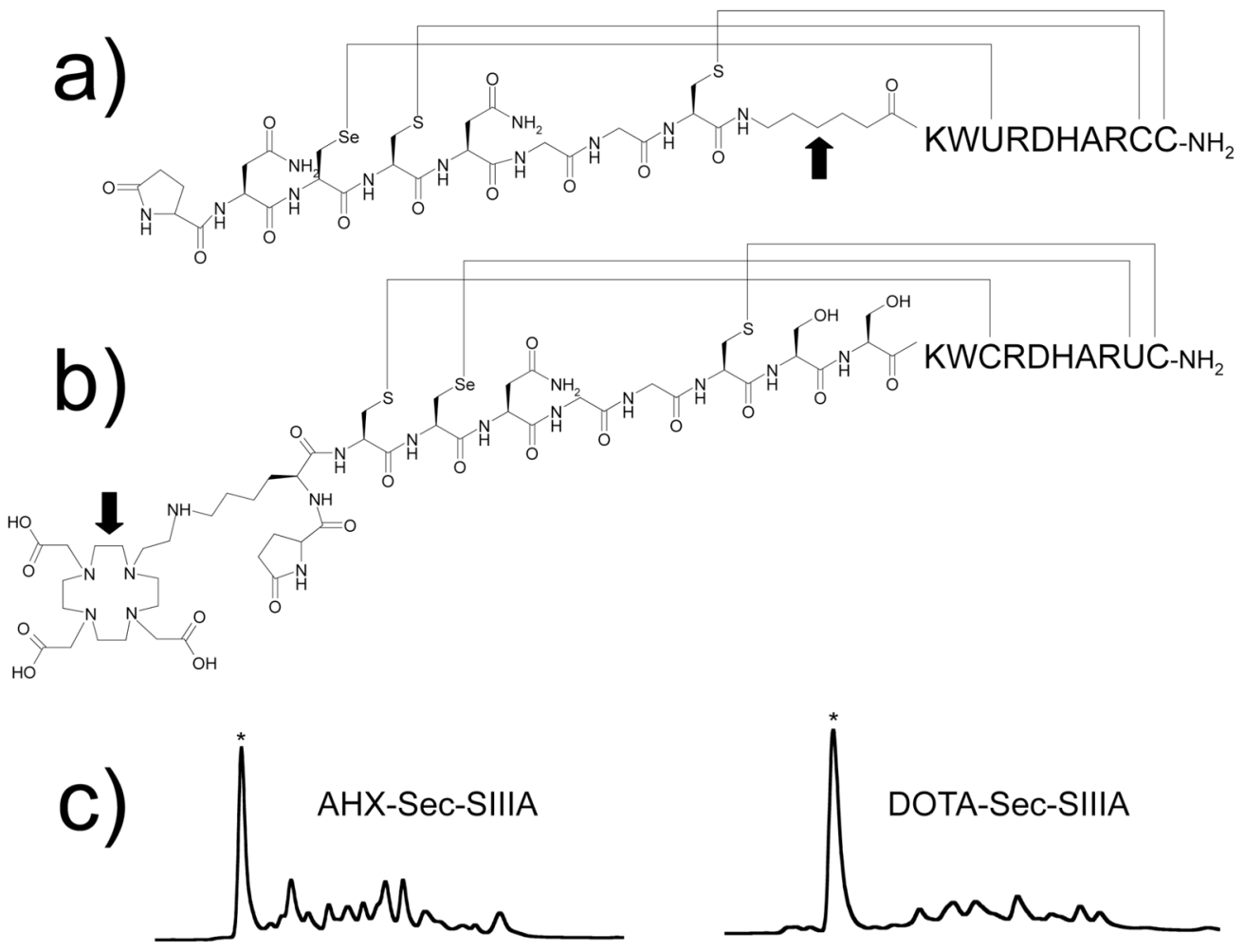

Figure 4.

Structures of AHX-Sec-SIIIA (a) and DOTA-Sec-SIIIA (b). Arrow points to the backbone spacer, 6-aminohexanoic acid, or the DOTA moiety. (c) HPLC elution profiles of the folding reactions. Asterisk indicates the folding species that was functionally characterized. 